\title{
Molecular Analysis of the $\beta$-Thalassemia
}

\section{Phenotype Associated with Inheritance of Hemoglobin $\mathrm{E}\left(\alpha_{2}{\beta_{2}}^{26} \mathrm{Glu} \rightarrow\right.$ Lys $)$}

\author{
Edward J. Benz, Jr., Brian W. Berman, Barry L. Tonkonow, and Elaine Coupal, \\ Hematology Section, Departments of Internal Medicine and Pediatrics, Yale \\ University School of Medicine, New Haven, Connecticut 06510 \\ Thomas Coates and Laurence A. Boxer, Division of Pediatric Hematology, \\ Indiana University School of Medicine and James Whitcomb Riley Hospital \\ for Children, Indianapolis, Indiana 46223 \\ Arnold Altman, Division of Pediatric Hematology, University of Connecticut \\ School of Medicine, Farmington, Connecticut 06032 \\ JuniUs G. ADAMS III, Hemoglobin Research Laboratory, Veteran's Administration \\ Hospital, University of Mississippi Medical Center, Jackson, Mississippi 39216
}

\begin{abstract}
A в S T R A C T Inheritance of the gene for $\beta^{E}$-globin is associated with hypochromia and microcytosis, reminiscent of typical heterozygous $\beta$-thalassemia. $\mathrm{Pa}$ tients with hemoglobin $(\mathrm{Hb}) \mathrm{E}-\boldsymbol{\beta}$-thalassemia exhibit clinical phenotypes of severe $\beta$-thalassemia, a circumstance not encountered in other compound heterozygous states for structural $\beta$-chain mutations and $\beta$ thalassemia. We have analyzed the kinetics of globin synthesis and the levels of globin messenger (m) RNA accumulation in patients with $\mathrm{Hb} \mathrm{E}-\boldsymbol{\beta}$-thalassemia and $\mathrm{Hb} E$ trait. The initial rate of $\beta$-globin synthesis $\left(\beta^{\mathrm{E}} / \alpha=0.20-0.34\right)$ was less than expected on the basis of gene dosage, or comparable studies of other compound heterozygous states for $\beta$-thalassemia and structurally abnormal $\beta$-chains. $\beta^{\mathrm{E}}$-globin synthesis was not only reduced during short-term incubations (1-5 min), but also remained relatively unchanged during long-term pulse or chase incubations up to $5 \mathrm{~h}$. Analysis of globin mRNA by cell-free translation and molecular hybridization confirmed that the unexpectedly low levels of $\beta^{\mathbb{E}}$-globin synthesis were associated with
\end{abstract}

Preliminary findings from these studies were presented at the 37th Annual Meeting of the American Federation for Clinical Research, 10-12 May 1980, in Washington, D. C. (Clin. Res. 28: 305A).

Address all correspondence to Dr. Benz, Hematology Section, Department of Internal Medicine, Yale University School of Medicine, New Haven, Conn. 06510.

Received for publication 15 August 1980 and in revised form 20 February 1981. comparable reductions in the levels of $\beta$-globin mRNA. In $\mathrm{Hb} \mathrm{E}-\beta$-thalassemia the $\beta^{\mathrm{A}}+\beta^{\mathrm{E}} / \alpha$ globin mRNA ratios observed were substantially lower than those obtained from reticulocytes of patients with heterozygous $\beta$-thalassemia, or $\mathrm{Hb} \mathrm{S}-\beta^{\circ}$-thalassemia, while in $\mathrm{Hb} \mathrm{E}$ trait, the $\beta^{\mathrm{A}}+\beta^{\mathrm{E}} / \alpha$ mRNA ratio was in the range observed for $\beta$-thalassemia trait. The $\beta^{E}$-globin gene specifies reduced accumulation of $\beta^{E}$-globin mRNA, a property characteristic of other forms of $\beta$-thalassemia. The $\beta$-thalassemia phenotype associated with inheritance of $\mathrm{Hb} \mathrm{E}$ is thus determined at the level of $\beta$ globin mRNA metabolism.

\section{INTRODUCTION}

Hemoglobin $(\mathrm{Hb})^{1} \mathrm{E}\left(\beta^{26 \mathrm{Glu} \rightarrow \mathrm{Lys}}\right)$ is the third most common hemoglobin variant worldwide; it is particularly prevalent among Southeast Asian individuals (1-3). Individuals heterozygous ( $\mathrm{Hb} \mathrm{E}$ trait) or homozygous ( $\mathrm{Hb} \mathrm{E}$ disease) for $\mathrm{Hb} \mathrm{E}$ exhibit microcytosis and erythrocyte morphology resembling $\beta$-thalassemia trait $(1-3)$. Double heterozygosity for $\mathrm{Hb} \mathrm{E}$ and $\beta$-thalassemia is frequently associated with a moderately severe $\beta$-thalassemia syndrome, the molecular basis of which has not been well defined (2-5). It has been suggested that the thalassemia-like phenotype of $\mathrm{Hb} \mathrm{E}$ disorders

\footnotetext{
${ }^{1}$ Abbreviations used in this paper: c, complementary (e.g., cDNA); Hb, hemoglobin; m, messenger (e.g., mRNA); MCV, mean corpuscular volume.
} 
results from impaired synthesis of $\beta^{E}$-globin (6-10), or, perhaps from $\beta^{E}$-globin chain instability $(11,12)$. Either mechanism could result in a limited supply of the abnormal $\beta$-globin chain and lead to decreased net accumulation of $\mathrm{Hb} \mathrm{E}$. To define more precisely the pathogenesis of $\mathrm{Hb} \mathrm{E}$ disorders, we have analyzed the kinetics of $\beta^{E}$-globin synthesis and the amounts of total $\beta$ messenger (m) RNA ( $\beta^{\mathrm{A}}+\beta^{\mathrm{E}}$ mRNA) in two patients with $\mathrm{Hb}$ E- $\beta$-thalassemia, and a patient with $\mathrm{Hb} \mathrm{E}$ trait. Our results support the concept that $\beta^{\mathrm{E}}$ globin is synthesized initially at a moderately decreased rate. Although $\beta^{\mathrm{A}}$ - and $\beta^{\mathrm{E}}$-mRNA could not be individually distinguished and quantified, the total $\beta$-mRNA ( $\beta^{\mathrm{A}}+\beta^{\mathrm{E}}$ mRNA) level was markedly reduced, suggesting that diminished $\beta^{E}$-globin synthesis was due to a comparable reduction in the amount of $\beta^{\mathrm{E}}$ globin mRNA. The gene coding for this $\beta$-globin structural variant thus exhibits features associated with most other forms of $\beta$-thalassemia genes.

\section{METHODS}

Patients. Two unrelated Southeast Asian patients with $\mathrm{Hb}$ E- $\beta$-thalassemia were studied. Hematologic parameters and family studies are summarized in Table I. Patient 1, a Vietnamese, had severe, transfusion-dependent anemia phenotypically simulating classical homozygous $\beta$-thalassemia. Patient 2 , of Thai extraction, had a $\beta$-thalassemia intermedia phenotype, with marked hypochromic, microcytic anemia and hepatosplenomegaly, but no chronic transfusion requirement. Neither patient had undergone splenectomy. Both exhibit typical thalassemic facies, growth retardation, and erythroid hyperplasia. Patients with $\mathrm{Hb}$ S- $\beta$-thalassemia and "classical" $\beta$-thalassemia who were studied have been described previously (13-16). In addition, the father of patient 1 , a heterozygote for $\mathrm{Hb} \mathrm{E}$, was studied (Table I). Other family members were unavailable for detailed study.

Preparation and radioactive labeling of reticulocytes. Erthrocytes from $50 \mathrm{ml}$ of peripheral blood were collected by centrifugation at $2,000 \mathrm{rpm}$ for $10 \mathrm{~min}$ at $2-4^{\circ} \mathrm{C}$ in a Sorvall RC-3 centrifuge (DuPont Instruments, Newtown, Conn.); the cells were washed three times in sterile isotonic saline. About $5 \mathrm{ml}$ of cells was set aside in an ice bath for incubation with either $\left[{ }^{35} \mathrm{~S}\right]$ methionine or $\left[{ }^{3} \mathrm{H}\right]$ leucine. The remainder of the cell pellet was suspended in ice-cold $5 \mathrm{mM}$ magnesium chloride, shaken vigorously, and incubated for $1 \mathrm{~min}$ on ice. The hemolysates were then extracted with phenol for preparation of reticulocyte RNA, using methods previously described (17).

The kinetics of globin synthesis were measured by pulsechase incubations with $\left[{ }^{3} \mathrm{H}\right]$ leucine or $\left[{ }^{35} \mathrm{~S}\right]$ methionine as follows: aliquots of cells were resuspended to hematocrits of 30-35 in an incubation mixture containing Krebs-Ringer phosphate buffer, glucose, iron, and $A B$ negative dialyzed plasma, exactly as described (18); the suspension was preincubated for $5 \mathrm{~min}$ at $37^{\circ} \mathrm{C}$ with gentle shaking prior to the addition of isotope. For short-term, pulse-chase labeling studies, $200 \mu \mathrm{Ci}$ of $\left[{ }^{3} \mathrm{H}\right]$ leucine was added to $3 \mathrm{~cm}^{3}$ of prewarmed cell suspension. The incubation was allowed to proceed for 1 or $5 \mathrm{~min}$ at $37^{\circ} \mathrm{C}$ in a shaking waterbath, at which time aliquots of $200 \mu \mathrm{l}$ were removed and quickly frozen in acetone-dry ice for later globin analysis. $10 \mathrm{mM}$ nonradioactive leucine was added to the remaining cell suspension, and the sample rapidly chilled in an ice-waterbath. The cells were pelleted at $0^{\circ} \mathrm{C}$ for $5 \mathrm{~min}$ at $2,000 \mathrm{rpm}$ in a Sorvall RC-3 centrifuge, and the cell pellet was resuspended in prewarmed incubation mixture containing $10 \mathrm{mM}$ nonradioactive leucine, at a hematocrit of 30-35\%. "Chase" incubations were then conducted at $37^{\circ} \mathrm{C}$ in a shaking waterbath for the times indicated in the text. At each time point, a 400- $\mu$ l aliquot was removed, quick-frozen, and stored at $-80^{\circ} \mathrm{C}$ for globin chain analysis. Long-term incubations of reticulocytes from patient 1 were conducted similarly, except that the radioactive precursor was $\left[{ }^{35} \mathrm{~S}\right]$ methionine (sp act $4 \mathrm{mmol}, 200$ $\mu \mathrm{Ci} / \mathrm{ml}$ cell suspension).

Globin chain analysis. Each cell pellet from the pulsechase labeling experiment was thawed in an equal volume of ice-cold $5 \mathrm{mM}$ magnesium chloride, and the resulting hemolysate either used directly to prepare globin or clarified by centrifugation for $30 \mathrm{~s}$ at 12,000 rpm in an Eppendorf tabletop centrifuge (Eppendorf Geratebau, Netherler, West Germany). Globin was prepared by acid-acetone precipitation, and globin chains were separated and quantitated by carboxymethylcellulose chromatography, using methods which we have described in detail elsewhere $(17,19)$. In preliminary experiments, we verified that the globin chain biosynthetic ratios of clarified lysates were essentially equal to

TABLE I

\begin{tabular}{|c|c|c|c|c|c|c|c|}
\hline & \multirow[b]{2}{*}{ Hematocrit } & \multirow{2}{*}{$\begin{array}{l}\text { Reticulocyte } \\
\text { count }\end{array}$} & \multirow[b]{2}{*}{ Erythrocytes } & \multirow[b]{2}{*}{ MCV } & \multicolumn{3}{|c|}{ Hb electrophoresis } \\
\hline & & & & & $\mathrm{Hb} \mathrm{A}$ & $\mathrm{Hb} \mathrm{F}$ & $\mathbf{H b E}+\mathbf{H b} \mathbf{A}_{2}$ \\
\hline & $\%$ & $\%$ & per $100 \mathrm{WBC}$ & $f$ & $\%$ & $\%$ & $\%$ \\
\hline Patient 1 & 21 & 6 & 6 & $75^{*}$ & $69^{*}$ & $16^{*}$ & $15^{*}$ \\
\hline Father & 46 & 2.6 & 0 & 84 & 63 & & 37 \\
\hline Mother & 37 & 1.2 & 0 & 69 & 94 & & 6 \\
\hline Brother & 41 & 0.3 & 0 & 71 & 68 & & 32 \\
\hline Brother & 40 & 0.3 & 0 & 83 & 97 & & 3 \\
\hline Patient 2 & 17.2 & 10.6 & 4 & 52 & $<5$ & 20 & 75 \\
\hline
\end{tabular}

Hematologic findings in patients with $\mathrm{Hb}$ E- $\beta$-thalassemia and available family members. None of patient 2's family members were available for study. However, family history was negative for transmission of severe anemia, except for the proband. The father of patient 1 had thalassemic erythrocyte morphology despite an MCV of 84 . WBC, leukocytes.

* Reflects contribution of transfused blood. 
those of the total hemolysate and membrane fractions regardless of whether samples from the $\mathrm{Hb} \mathrm{E}$ patients or from nonthalassemic controls were examined. Over $90 \%$ of the radioactive globin was in the clarified lysate. No preferential accumulation of globin chains in the insoluble membrane fraction was observed (see Results, Table III). Globin chain biosynthetic ratios were calculated by comparing the total radioactivity present within optical density peaks defined by authentic nonradioactive globin chain markers included in the chromatographic analysis. In the case of $\left.{ }^{35} \mathrm{~S}\right]$ methionine studies, the measured non- $\alpha / \alpha$ ratios were doubled, to account for the presence of two methionine ratios in $\alpha$-globin, but only one in the relevant non- $\alpha$ globins (20).

The production of $\beta^{E}$-globin by both patients was also verified by "fingerprint" mapping of peptides resulting from tryptic digests of nonradioactive globin from each patient, using methods previously described in detail (21). Globin from both patients yielded the characteristic fingerprint of patients producing both $\beta^{\mathrm{A}}$ - and $\beta^{\mathrm{E}}$-globins: loss of intensity from the $\beta$ T3 peptide spot, and generation of two new spots, one of which is detectable by arginine staining. In both cases, the two new spots migrated in the characteristic positions of $\beta^{E}$-globin. These results were entirely typical of patients heterozygous for $\beta^{A}$ - and $\beta^{E}$-globin. In addition, a portion of the radioactive globin from both patients comigrated with authentic $\beta^{E}$-globin marker on carboxymethylcellulose columns.

Extraction and analysis of reticulocyte RNA. Total reticulocyte cellular RNA was prepared by phenol extraction and alcohol precipitation as described previously by this laboratory (17, 19). RNA was desalted by centrifugation through a Sephadex G-25 (coarse) syringe column (22), and used directly for further analysis without purification of globin mRNA fractions. Cell-free translations in wheat germ extracts were performed utilizing methods described in detail elsewhere, as was molecular hybridization analysis, utilizing radioactive, purified $\alpha$ - and $\beta$-globin cDNA hybridization probes (13-17, 19). Globin chains synthesized in cell-free translation systems primed with reticulocyte RNA were analyzed by carboxymethylcellulose chromatography after addition of authentic globin chain markers, as described in the preceding section. $\beta / \alpha$ mRNA ratios assessed by molecular hybridization were obtained by saturation hybridization analysis, comparing the slopes obtained from titration of equal amounts of $\alpha$ - and $\beta$ cDNA by increasing amounts of each RNA sample, as described elsewhere (14-16). However, hybridization reactions were conducted under conditions which we have previously shown (14-16) to prohibit cross-hybridization among $\beta-, \delta-, \epsilon-$, and $\gamma$-mRNA and cDNA sequences. The molecular hybridization analyses do not distinguish between $\beta^{\mathrm{A}}$ - and $\beta^{\mathrm{E}}$-mRNA, since these mRNA most likely differ only in one or a few base pairs. Traeger and co-workers (23) have recently observed that $\beta^{E}$-mRNA hybridizes efficiently to $\beta$ cDNA probes with properties identical to ours. The hybridization assay thus measures the total content of $\beta$-mRNA sequences relative to $\alpha$-mRNA (i.e., $\beta^{A}+\beta^{E} / \alpha$ mRNA) and does not allow individual quantitation of the relative amounts of $\beta^{A}$ - and $\beta^{E}$-mRNA (i.e., $\beta^{E} / \beta^{A}$ mRNA). Therefore, deficiency of $\beta^{E}$-mRNA can be inferred only if the $\beta^{A}+\beta^{E} / \alpha$ mRNA ratio is too low to be due solely to the $\beta^{A}$ mRNA produced by the normal $\left(\beta^{\mathrm{A}}\right)$ or $\beta^{\text {thal }}$-gene present in trans to the $\beta^{\mathbb{E}}$-gene.

\section{RESULTS}

Characteristics of patients and initial rates of globin biosynthesis. Table I shows the hematologic characteristics of the probands and their available relatives. The two relatives of patient 1 with $\mathrm{Hb} E$ trait have typical hemoglobin electrophoretic values for $\mathrm{Hb} \mathrm{E}$ (37 and $32 \%$ ), well within the ranges reported by others $(1-10)$. The mother of patient 1 has $\beta$-thalassemia trait with an elevated $\mathrm{Hb} \mathrm{A}_{2}$. Patient 2 had no relatives available for study but exhibits typical features of $\mathrm{Hb} \mathrm{E}-\beta$-thalassemia with a low output $\beta$ thalassemia allele inherited in trans to the $\beta^{E}$-globin allele. The high percentage of $\mathrm{Hb} \mathrm{A}$, low percentage of

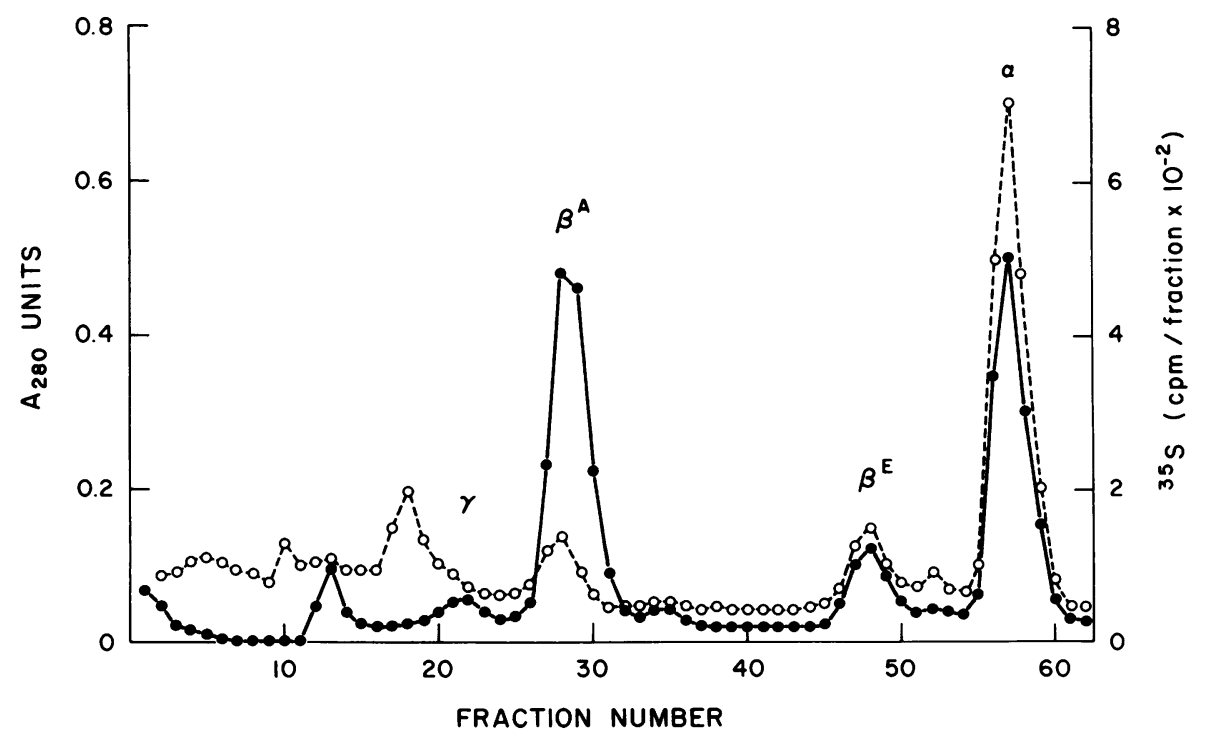

FIgURE 1 Globin synthesis by intact reticulocytes from patient 1 with $\mathrm{Hb}$ E- $\beta$-thalassemia. Reticulocytes were incubated with $\left[{ }^{35} \mathrm{~S}\right]$ methionine for $1 \mathrm{~min}$ and the radioactive proteins fractionated by carboxymethylcellulose chromatography, as described in the text. The closed circles indicate the optical density at $280 \mathrm{~nm}$ of authentic $\gamma-, \beta^{A_{-}}, \beta^{E_{-}}$, and $\alpha$-globin mRNA. The open circles indicate ${ }^{35} \mathrm{~S}$ counts per minute in each fraction. 


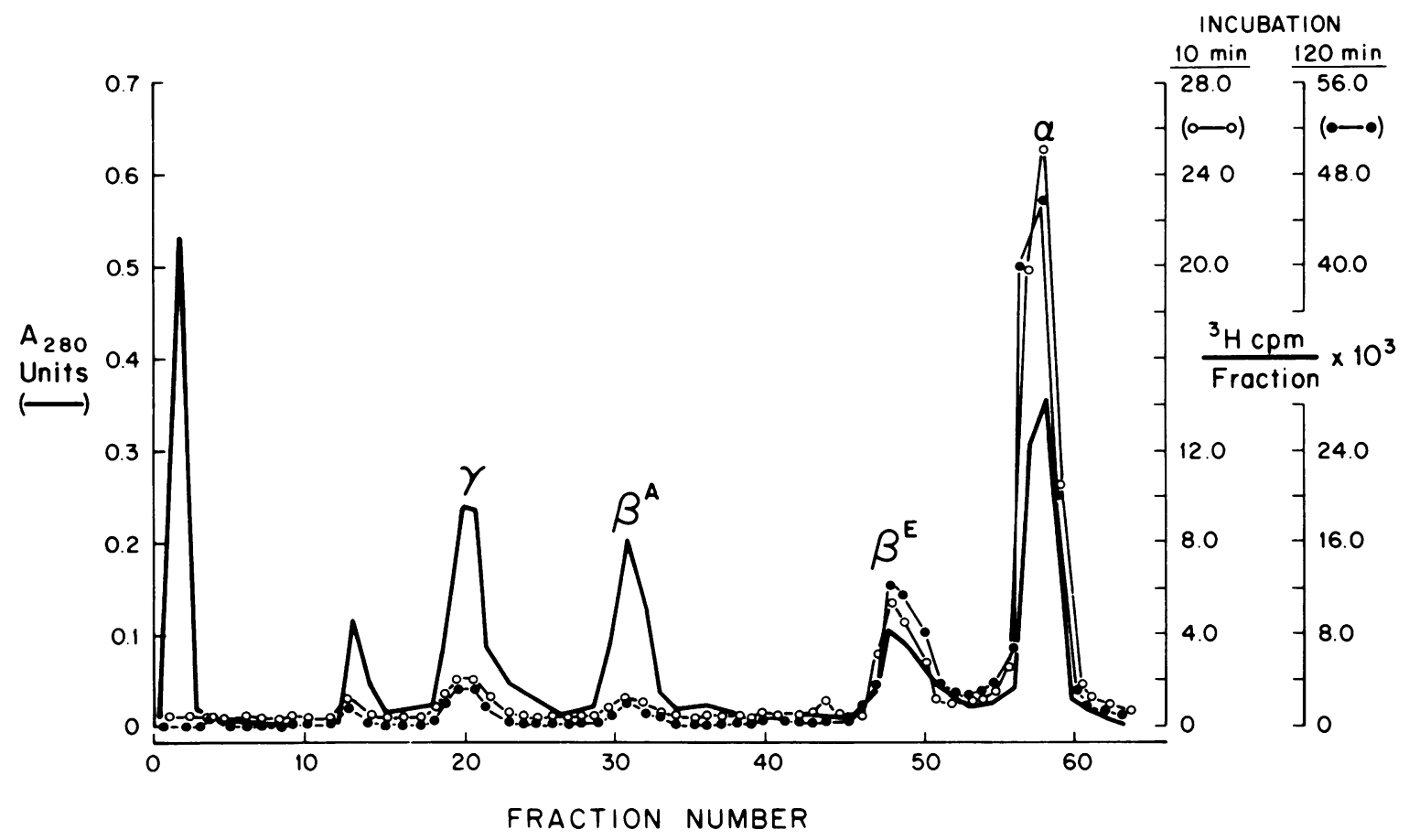

FIGURE 2 Globin synthesis by intact reticulocytes from patient 2 with $\mathrm{Hb}$ E- $\beta$-thalassemia. Experimental conditions were essentially as described in Fig. 1, except that $\left[{ }^{3} \mathrm{H}\right]$ leucine was used as the isotope, and the incubations were for $10 \mathrm{~min}$ (open circles) and $120 \mathrm{~min}$ (closed circles).

$\mathrm{Hb} \mathrm{E}$, and relatively high $\mathrm{MCV}$ of patient 1 are due to the presence of transfused normal cells. Patients 1 and 2 , and the father of patient 1 , with $\mathrm{Hb} \mathrm{E}$ trait, consented to further study.

Results obtained by analysis of globin radioactivity after short-term incubations of intact reticulocytes are shown in Fig. 1 for patient 1 and Fig. 2 for patient 2. Patient 1 appears to have inherited a $\beta^{+}$-thalassemia gene in trans to the $\beta^{\mathrm{E}}$-globin gene, as indicated by the consistent $\beta^{\mathrm{A}} / \alpha$ biosynthetic ratios of 0.1-0.2 (Figs. 1 and 3). The $\beta$-thalassemia gene in patient 2 is a $\beta^{+}$thalassemia gene associated with lower $\beta$-globin output $\left(\beta^{\mathrm{A}} / \alpha=0.02-0.05\right)$, as shown in Figs. 2 and 4 . In both cases, the initial levels of $\beta^{E}$-globin synthesis during 1- or 5-min "pulse" incubations $\left(\beta^{\mathrm{E}} / \alpha=0.20\right.$ in patient 1 , and 0.33 in patient 2) were lower than expected on the basis of inheritance of a normally functioning $\beta$ globin gene in trans to the $\beta$-thalassemia allele; the ratios were comparable to results reported by others $(1-10)$. As indicated in Table II, we observed $\beta / \alpha$ ratios of $>0.4$ attributable to the normally functioning $\beta^{\mathrm{A}}$ - or $\beta^{\mathrm{S}}$-globin gene inherited in trans to $\beta$ thalassemia genes in patients with $\beta$-thalassemia trait, or $\mathrm{Hb} \mathrm{S}-\beta$-thalassemia, or the $\beta^{\mathrm{S}}$ - and $\beta^{\mathrm{C}}$-genes coinherited in $\mathrm{Hb}$ sickle cell disease. These findings are also consistent with those of other laboratories $(2,3,7$, 24-29). As shown in Table II, total $\beta$-globin chain synthesis $\left(\beta^{\mathrm{A}}+\beta^{\mathrm{E}} / \alpha\right)$ observed in reticulocytes of the two patients with $\mathrm{Hb} E$ - $\beta$-thalassemia fell into the range observed among patients with homozygous $\beta$ thalassemia.

As shown in Table III, $>90 \%$ of the radioactive globin synthesized in our experiments could be recovered in clarified supernatant fractions. The globin biosynthetic ratios were nearly identical in total hemolysates, membrane pellets, and supernatant frac-

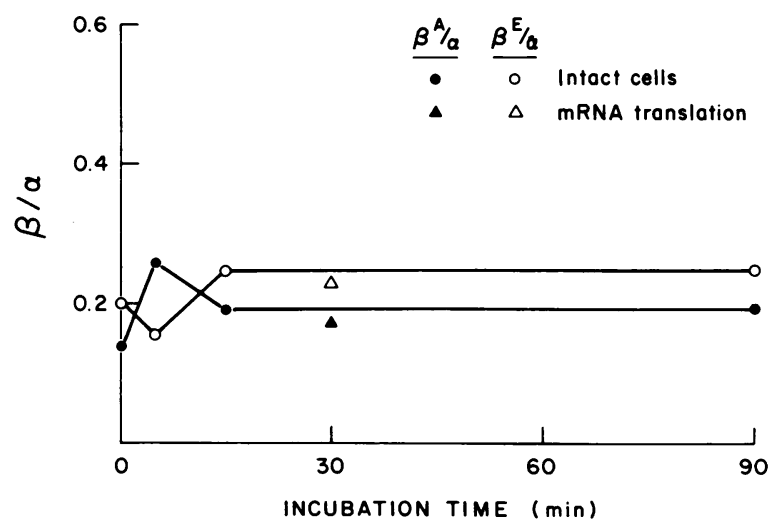

FIgURE 3 Kinetics of $\beta^{\mathrm{A}}$ - and $\beta^{\mathrm{E}}$-globin synthesis in patient 1 with $\mathrm{Hb}$ E- $\beta$-thalassemia. Data were obtained as described in the text and are illustrated in Fig. 1. Open symbols indicate $\beta^{E} / \alpha$ ratios, and closed symbols, $\beta^{\mathrm{A}} / \alpha$ ratios. Results obtained from intact reticulocyte incubations are shown by circles; results obtained by analysis of $\left.{ }^{35} \mathrm{~S}\right]$ methionine proteins synthesized in a wheat germ cell-free system primed with reticulocyte mRNA from patient 1 are shown by triangles. 


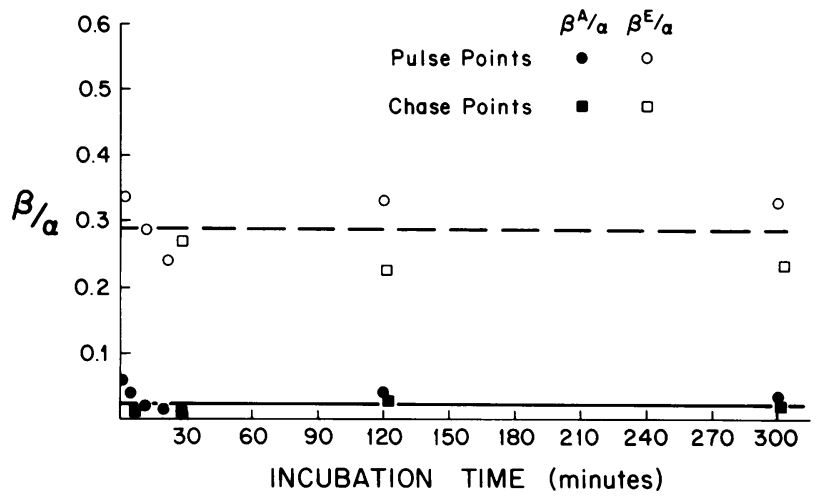

FIgURE 4 Kinetics of $\beta^{A}$ and $\beta^{E}$-globin synthesis in intact reticulocytes from patient 2 with $\mathrm{Hb} \mathrm{E}$ - $\beta$-thalassemia. Data were obtained as described in the text and are illustrated in Fig. 2. $\beta^{\mathrm{A}} / \alpha$ ratios are indicated by closed symbols, and $\beta^{\mathrm{E}} / \alpha$ ratios, by open symbols. Pulse incubations (circles) were conducted for the times indicated on the abscissa. Chase incubations (squares) were conducted under conditions described in Methods after a 5-min pulse incubation; the chase time is plotted along the abscissa exclusive of the 5min pulse incubation time.

tions. No selective precipitation of $\beta^{\mathrm{E}}$-globin or $\mathrm{Hb} \mathrm{E}$ was apparent.

The father of patient 1 , who has $\mathrm{Hb} \mathrm{E}$ trait, synthesized less $\beta^{\mathrm{E}}$-globin $\left(\beta^{\mathrm{E}} / \alpha=0.26\right)$ than $\beta^{\mathrm{A}}$-globin $\left(\beta^{\mathrm{A}} / \alpha=0.42\right)$, as shown in Table III. No sequestration of $\beta^{E}$-globin on membranes was observed. The $\beta^{\mathrm{E}} / \beta^{\mathrm{A}}$ biosynthetic ratio after $30 \mathrm{~min}$ incubation was 0.61 (Table III), a value which correlated well with the relative proportions of $\mathrm{Hb} \mathrm{E}$ and $\mathrm{Hb} \mathrm{A}$ in circulating reticulocytes $(\mathrm{Hb} \mathrm{E} / \mathrm{Hb} \mathrm{A}=0.59)$. Similar comparisons of biosynthetic ratios to circulating $\mathrm{Hb} \mathrm{A}$ and $\mathrm{Hb} \mathrm{E}$ in the two $\mathrm{Hb} \mathrm{E}$ - $\beta$-thalassemia patients could not be made because of the presence of transfused $\mathrm{Hb} \mathrm{A}$ erythrocytes in patient 1 and the very small amounts of $\mathrm{Hb} \mathrm{A}$
TABLE III

\begin{tabular}{lcccc}
\hline & $\beta^{\wedge} / \alpha$ & $\beta^{\mathrm{E} / \alpha}$ & $\beta^{\mathrm{A} / \beta^{\mathbb{E}}}$ & $\begin{array}{c}\text { Total } \\
{\left[{ }^{\mathrm{B}} \mathrm{H}\right] \mathrm{globin}}\end{array}$ \\
\hline Total hemolysate & & & & $\%$ \\
Clarified supernate & 0.42 & 0.26 & 0.61 & 100 \\
Membrane fraction & 0.41 & 0.27 & 0.64 & 93.4 \\
& 0.51 & 0.28 & 0.55 & 5.8 \\
\hline
\end{tabular}

Globin synthesis in $\mathrm{Hb}$ E trait. Peripheral blood $(2 \mathrm{ml})$ from the father of patient 1 was incubated with $\left[{ }^{3} \mathrm{H}\right]$ leucine and the cells lysed as described in Methods. Globin was prepared from total hemolysate, the clarified lysate (supernatant fraction) after centrifugation at $12,000 \mathrm{~g}$ for $10 \mathrm{~min}$, and the pellet (membrane fraction). Individual $\left[{ }^{3} \mathrm{H}\right]$ globins were analyzed from each fraction by carboxymethylcellulose chromatography as described in Methods. "Total globin" refers to the percentage of total radioactive $\left[{ }^{3} \mathrm{H}\right]$ globin counts per minute (cpm) (sum of net cpm in $\beta^{\mathbf{A}}, \beta^{\mathbb{E}}$, and $\alpha$-globin peaks) in each fraction, using the total hemolysate cpm as an arbitrary standard of $100 \%$. Similar studies of patients 1 and 2 showed no detectable $\beta^{\mathrm{A}}$ or $\beta^{\mathrm{E}}$-globin in the membrane fraction at 1 or $60 \mathrm{~min}$.

and $\beta^{\mathrm{A}}$-globin synthesis in patient 2 . The results argue against a posttranslational mechanism in $\mathrm{Hb} \mathrm{E}$ trait which would yield a $\beta^{\mathrm{E}} / \beta^{\mathrm{A}}$ biosynthetic ratio of 1.0 ; the lower $\mathrm{Hb} \mathrm{E} / \mathrm{Hb} \mathrm{A}$ ratio in the blood would result from a selective decline of $\beta^{\mathrm{E}}$-globin subsequent to biosynthesis, a phenomenon not supported by our data.

Kinetics of $\beta^{\mathrm{E}}$-globin synthesis in intact reticulocytes. The possibility of selective post-translational catabolism of $\beta^{\mathrm{E}}$-globin was examined by kinetic analysis of globin synthesis. Globin chain biosynthetic ratios obtained from each patient at varying times of pulse and chase incubation are displayed in Figs. 3 and 4. The relative ratios of $\alpha, \beta^{A_{-}}$, and $\beta^{E}$-globin synthesis remained essentially unchanged during both pulse and

\section{TABLE II}

\begin{tabular}{lccccc}
\hline & & \multicolumn{4}{c}{$\beta / \alpha$ ratio } \\
\cline { 3 - 6 } \multicolumn{1}{c}{ Syndrome } & $\begin{array}{c}\text { Patients } \\
\text { studied }\end{array}$ & $\beta^{\wedge} / \alpha$ & $\beta^{\mathrm{c} / \alpha}$ & $\beta^{\mathrm{\Sigma} / \alpha}$ & $\beta^{\mathrm{s} / \alpha}$ \\
\hline Normal Hb A & 5 & $0.97-1.0$ & & & \\
Sickle cell anemia & 4 & & 0.50 & 0.51 & \\
Hb SC disease & 1 & & & $0.43-0.49$ \\
Hb S- $\beta^{\text {o }}$-thalassemia & 3 & 0.00 & & & \\
$\beta$-Thalassemia trait & 4 & $0.42-0.55$ & & 0.26 & \\
Hb E trait & 1 & 0.42 & & 0.24 & \\
Hb E- $\beta$-thalassemia, Pt. \# 1 & 1 & 0.15 & & 0.33 & \\
Hb E- $\beta$-thalassemia, Pt. \#2 & 1 & 0.05 & & \\
Homozygous $\beta$-thalassemia & 13 & $0-0.38$ & & & \\
\hline
\end{tabular}

Synthesis of $\beta^{\mathrm{A}}$-globin and $\beta$-globin variants in various nonthalassemic and $\beta$-thalassemic reticulocytes. Data were obtained as described in the text and illustrated in Figs. 1 and 2. Some of these results have been presented in earlier communications (13-17). Data shown in the table represent entire range of values obtained from 30,90 , or 120 -min incubations with radioactive amino acid. 
chase incubations of up to $5 \mathrm{~h}$. There was no evidence for a time-dependent selective decline of $\beta^{E}$-globin, a trend which should be apparent for a structurally abnormal globin exhibiting post-translational instability. Thus, these data do not support the hypothesis that defective $\beta^{\mathrm{E}}$-globin production is mediated primarily at the level of posttranslational instability. In all of these experiments, the amounts of $\gamma$-globin synthesis observed were low despite relatively high levels of $\mathrm{Hb} \mathrm{F}$ in the peripheral blood of the probands (Table I). These findings are also routinely observed during our studies of many patients with a homozygous $\beta$-thalassemia (data not shown), and probably reflect the selective survival of $\mathrm{Hb}$ F-bearing cells (which are thus older, nonglobin synthesizing erythrocytes) in nonsplenectomized $\beta$-thalassemic patients.

Analysis of reticulocyte globin mRNA. Total cellular RNA prepared from reticulocytes of each patient was translated into globin chains in a wheat germ extract cell-free system, as noted in Methods. The globin biosynthetic ratios observed by this technique were similar to those observed in intact cells for patient 1 (cf. Fig. 3). Precise quantitation of globin biosynthetic ratios could not be computed for patient 2 because of relatively high background nonglobin radioactivity comigrating in this region of chromatogram. However, the $\beta^{\mathrm{E} / \alpha}$ ratio, including the nonglobin peaks, remained clearly $<0.30$ with this mRNA preparation. These data are summarized in Table IV. The level of $\beta^{E}$-globin synthesis in the cell-free translation system primed with mRNA from the proband was substantially lower than the levels of $\beta^{\mathrm{S}}$. globin synthesis obtained from studies of two patients with $\mathrm{Hb} \mathrm{S}-\beta^{\circ}$-thalassemia (see also reference 30,31 ). These experiments indicate that a defect in the amount and/or function of $\beta^{E}$-globin mRNA occurs in these reticulocytes, and is sufficiently severe to account for reduced $\beta^{\mathrm{E}}$-globin production.
To obtain more reliable quantitative data concerning the actual chemical amounts of $\alpha$ - and $\beta$-globin mRNA in reticulocytes from the probands, saturation hybridization analysis was performed as described in Methods and shown in Fig. 5. Under the conditions of hybridization employed, cross-hybridization between $\beta^{E}$-globin mRNA and $\beta^{A}$-globin cDNA is virtually $100 \%$, since a single base mutation does not appreciably alter the stability of RNA-cDNA hybrids in this system (23). The assay does not permit individual quantitation of $\beta^{\mathrm{A}}$-mRNA relative to $\beta^{\mathrm{E}}$ mRNA. In contrast, we have repeatedly shown (1316) that the hybridization conditions employed reproducibly detect $\beta$-mRNA without cross-hybridization to $\gamma$-mRNA. RN.A from both patients exhibited a striking decrease in the total $\beta$ globin mRNA content (i.e., $\beta^{\mathrm{A}}+\beta^{\mathrm{E}} / \alpha$ ratio). The total $\beta / \alpha$ mRNA ratios observed were 0.28 for patient $1,0.20$ for patient 2 , and 0.49 in the patient with $\mathrm{Hb} \mathrm{E}$ trait (Fig. 6). These results are compared with those of patients with typical heterozygous and homozygous thalassemic disorders, and with nonthalassemic reticulocyte RNA preparations in Figs. 6 and 7. The values observed for patients with $\mathrm{Hb} \mathrm{E}-\beta$-thalassemia fall in the range typically observed for patients with homozygous $\beta$ thalassemia. The ratio obtained in $\mathrm{Hb} \mathrm{E}$ trait matches most closely those obtained for patients heterozygous for $\beta$-thalassemia. One can infer a deficit in $\beta^{E}$-globin mRNA in these patients despite the indirect nature of the measurements, since, in each case, the $\beta$-globin allele inherited in trans cannot be solely responsible for the low ratios observed.

\section{DISCUSSION}

Our studies demonstrate that the $\beta$-thalassemia phenotype associated with $\mathrm{Hb} \mathrm{E}$ is due to a primary reduction of $\beta^{\mathrm{E}}$-globin synthesis resulting from decreased

\section{TABLE IV}

\begin{tabular}{|c|c|c|c|c|c|}
\hline \multirow[b]{2}{*}{ Syndrome } & \multirow{2}{*}{$\begin{array}{l}\text { Patients } \\
\text { studied }\end{array}$} & \multicolumn{4}{|c|}{$\beta / \alpha$ ratios } \\
\hline & & $\beta^{\wedge} / \alpha$ & $\beta^{c / \alpha}$ & $\beta^{\mathbb{E} / \alpha}$ & $\beta^{\mathrm{s} / \alpha}$ \\
\hline Normal $\mathrm{Hb} \mathrm{A}$ & 5 & $1.1-1.8$ & & & \\
\hline Sickle cell anemia & 4 & & & & $1.09-1.6$ \\
\hline Hb SC disease & 1 & & 0.59 & & 0.48 \\
\hline Hb S- $\beta^{\circ}$-thalassemia & 3 & 0.00 & & & $0.43-0.60$ \\
\hline$\beta$-thalassemia trait & 1 & 0.46 & & & \\
\hline Hb E- $\beta$-thalassemia (Patient 1 ) & 1 & 0.15 & & 0.23 & \\
\hline Hb E- $\beta$-thalassemia (Patient 2) & 1 & $<0.05$ & & $<0.30^{*}$ & \\
\hline Homozygous $\beta$-thalassemia & 14 & $0-0.47$ & & & \\
\hline
\end{tabular}

Globin messenger RNA translation in various nonthalassemic and $\beta$-thalassemic conditions. mRNA translation analysis was conducted as described in Methods. Data shown represent the range of $\beta / \alpha$ globin ratios obtained after cell-free translation from all patients of each category studied.

* $\beta^{E}$-globin product peak partially obscured by nonglobin background contaminant. Total radioactivity under $\beta^{E}$-globin peak was $\sim 28 \%$ of $\alpha$-radioactivity. 


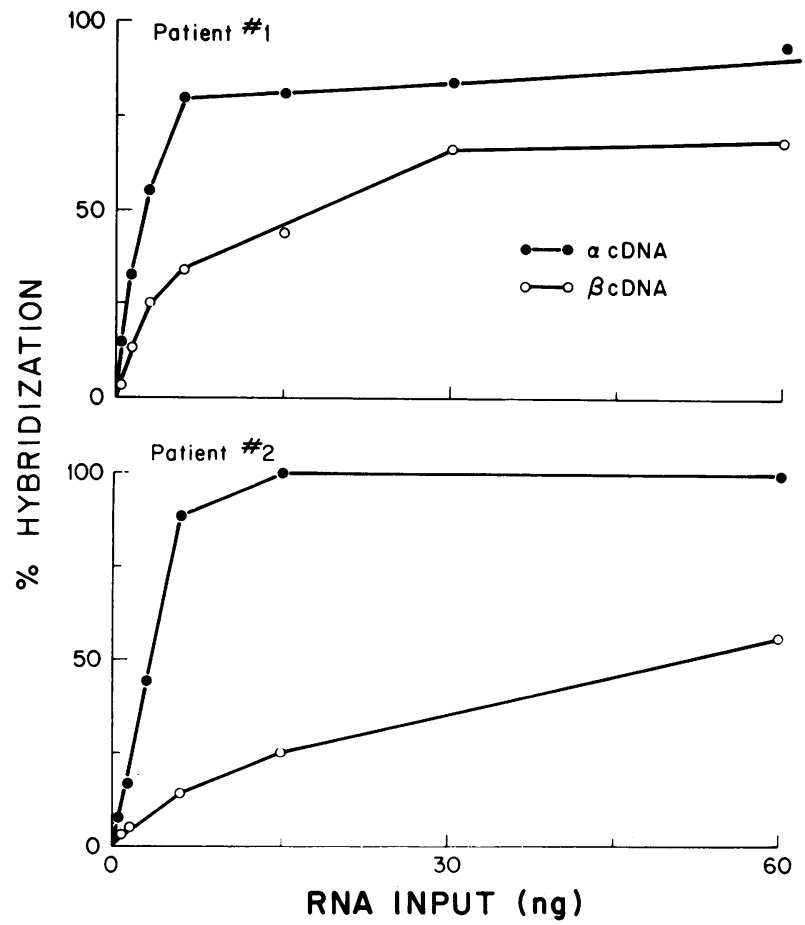

Figure 5 Molecular hybridization analysis of $\mathrm{Hb}$ E- $\beta$-thalassemia reticulocyte RNA. Reticulocyte RNA from each patient was prepared and analyzed as described in Methods. Each reaction contained the indicated amount of RNA, and $1,000 \mathrm{cpm}$ of $\alpha$-cDNA (closed circles) or $\beta$-cDNA (open circles). The specific activity of each cDNA was $50.4 \mathrm{Ci} / \mathrm{mmol}$. The $\alpha$-cDNA contained 5\% $\beta$-cDNA sequences, and the $\beta$ cDNA, $18 \% \alpha$-cDNA sequences. The early slope transitions in each $\beta$-cDNA curve represent hybridization of $\alpha$-mRNA in the RNA samples to the $\alpha$-cDNA contaminant of $\beta$-cDNA. RNA from patient 2 achieved $70-75 \%$ saturation of the $\beta$-cDNA probe at 120 and $240 \mathrm{ng}$ RNA inputs. $\beta^{\mathrm{A}}+\beta^{\mathrm{E}} / \alpha$ mRNA ratios were calculated from the RNA inputs required to achieve half saturation of the $\alpha$-and $\beta$-cDNA probes. The values of percent hybridization achieved at saturation with these mRNA and cDNA are identical to those observed in parallel experiments using these cDNA and well-characterized $\alpha-, \beta-$, and nonthalassemic mRNA (cf. reference 13-16, Fig. 6).

accumulation of $\beta^{E}$-globin mRNA. We have eliminated posttranslational mechanisms as possible causes for the reduced $\mathrm{Hb} \mathrm{E}$ production. Since the original submission of this manuscript, Traeger et al. (23) have reported similar conclusions. Both their results and ours suggest that the $\beta^{\mathrm{E}}$-globin gene behaves like a mild $\beta$-thalassemia gene, since $\beta$-mRNA levels range near the upper limits observed for patients with comparable numbers of $\beta$-thalassemia genes (Fig. 7, Table IV). These observations are consistent with the mild hypochromic anemia seen in homozygotes for $\mathrm{Hb} \mathrm{E}$ $(1-10)$. However, the $\beta^{E}$-gene is sufficiently "thalassemic" to interact with a true $\beta$-thalassemia allele to produce severe clinical phenotypes seen in $\mathrm{Hb} \mathrm{E}-\beta$ thalassemia. The $\beta^{\mathrm{E}}$-globin gene thus resembles the mild $\beta$-thalassemia allele possessed by "silent carriers" of $\beta$-thalassemia (reference 2,3 ).
A
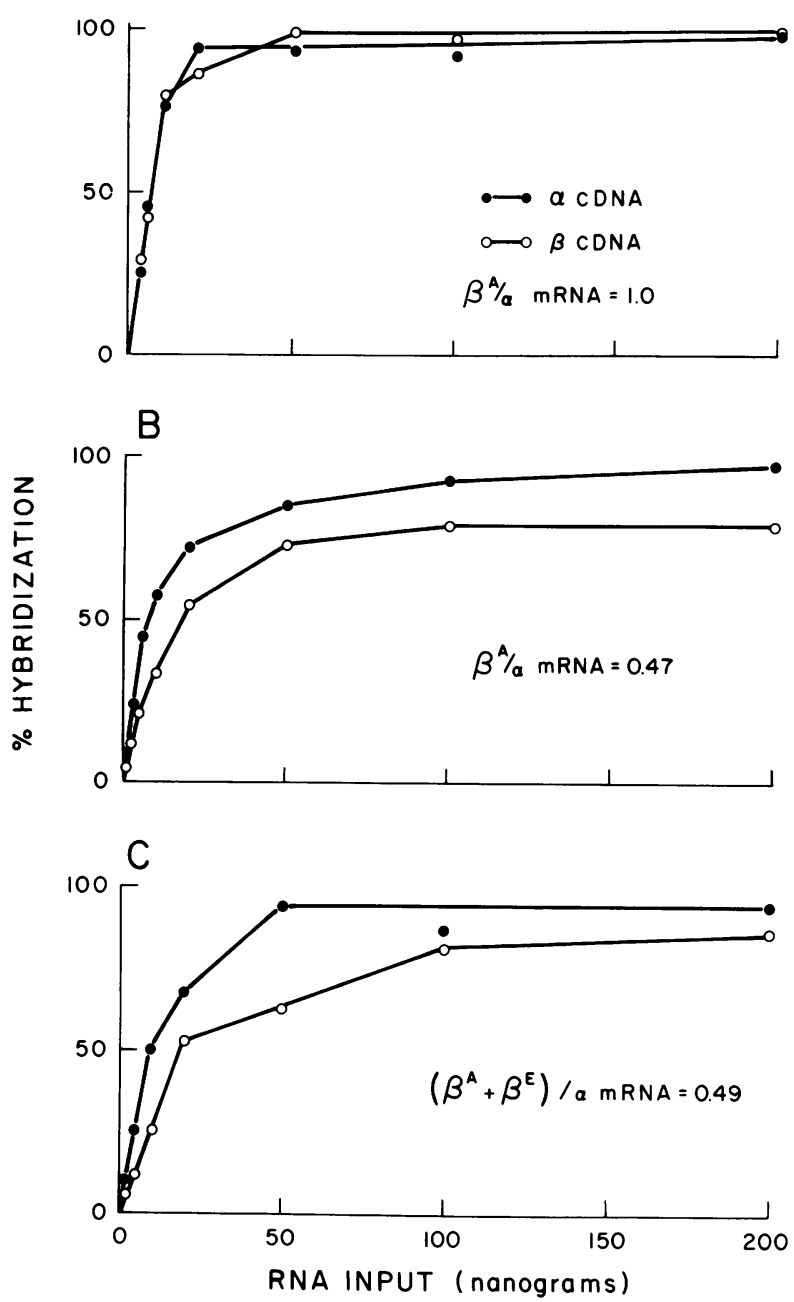

Figure 6 Molecular hybridization analysis of $\mathrm{Hb} \mathrm{E}$ trait reticulocyte RNA. RNA preparation and hybridization analysis were performed as described in Fig. 5. Nonthalassemic reticulocytes (A) were obtained from a patient with paroxysmal nocturnal hemoglobinuria, $\mathrm{Hb} \mathrm{E}$ trait reticulocytes (C) from the father of patient 1 , and $\beta$-thalassemia trait reticulocytes (B) from an adult with typical heterozygous $\beta$-thalassemia.

Because of the recent influx of Southeast Asian immigrants, $\mathrm{Hb} \mathrm{E}$ is being encountered with increasing frequency in Western nations. $\beta$-Thalassemia is also very common in these populations $(2,3)$. For purposes of genetic counseling, therefore, it is important to recognize the $\beta^{\mathrm{E}}$-globin gene as a mild $\beta$ thalassemia allele. The potential genetic combination of $\mathrm{Hb} \mathrm{E}$ and $\beta$-thalassemia is of far greater clinical significance than potential homozygosity for $\mathrm{Hb} \mathrm{E}$. $\mathrm{Hb} \mathrm{E}$ itself is apparently compatible with normal oxygen delivery and erythrocyte homeostasis $(9,10)$, despite mild instability demonstrable in vitro $(32,33)$.

Our studies of family 1 (Figs. 1 and 3 , Table III) suggest lower levels of $\beta^{\mathrm{E}}$-globin synthesis than in patient 2 (Figs. 2 and 4). Similar heterogeneity of $\beta^{\mathrm{E}} / \alpha$ bio- 


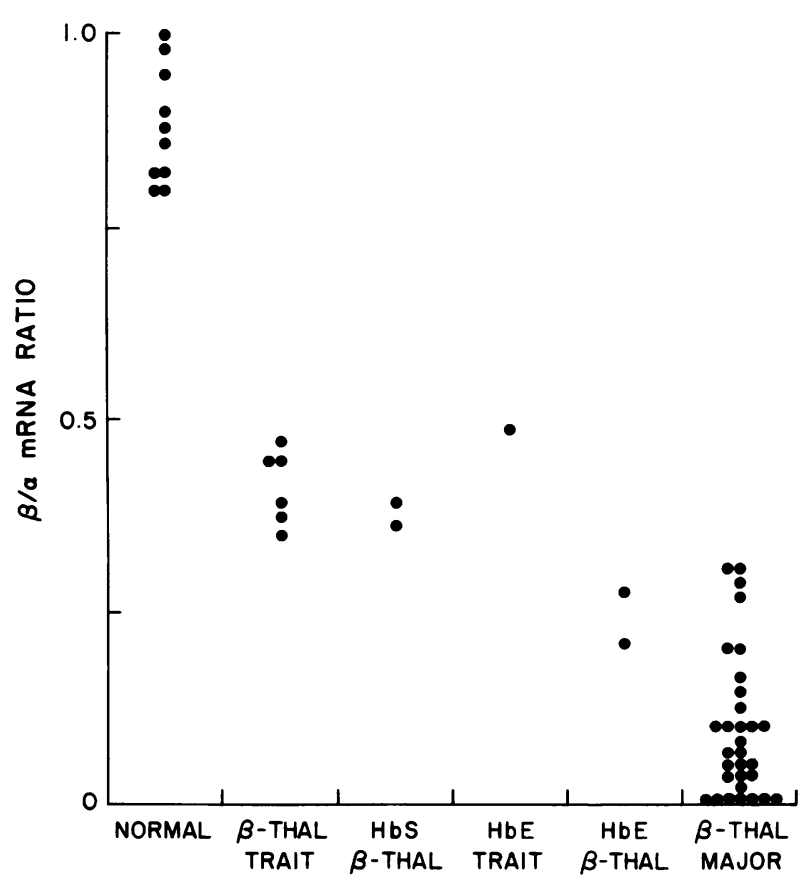

FIGURE $7 \beta$ mRNA content in various $\beta$-thalassemia syndromes. Data were obtained by molecular hybridization analysis as illustrated in Figs. 5 and 6 . Some of the data for patients with homozygous $\beta$-thalassemia were derived from our previous studies (13-16). Nonthalassemic $\beta / \alpha$ mRNA ratios range from 0.8 to 1.0 , reflecting the normal $5-20 \%$ excess of $\alpha$-mRNA in reticulocytes.

synthetic ratios $(0.2-0.4)$ has been encountered by others $(1-10,23)$. However, $\mathrm{Hb} \mathrm{E}$ invariably constitutes $30-39 \%$ of total circulating hemoglobin in heterozygotes (1-10,23, present study), suggesting technical variation rather than true genetic heterogeneity of $\beta^{\mathrm{E}}$-globin alleles in different families. It is likely that the variability results from the close proximity of the $\beta^{\mathrm{E}}$-globin peak to $\alpha$ - and pre- $\alpha$ (carbamylated $\alpha$-chains) peaks, which renders precise quantitation difficult. The presence of $\alpha$-thalassemia among these patients could also contribute to heterogeneity, but cannot explain the apparent $\beta$-thalassemic behavior of the $\beta^{E}$-gene reported in this communication. Indeed, $\alpha$-thalassemia would tend to "mask" the lowered $\beta^{\mathrm{E}}$-globin and $\beta^{\mathrm{E}}$-globin mRNA levels observed by lowering $\alpha$-globin and $\alpha$-globin mRNA. The recently described condition in which more than the normal number of $\alpha$-genes are inherited (34) could conceivably account for our data if the extra $\alpha$-genes were functional. However, these genes do not appear to alter $\alpha$ - and $\beta$-globin balance in patients studied thus far (35). In any event, this hypothesis cannot explain the lower production of $\beta^{\mathrm{E}}$-globin than $\beta^{\mathrm{A}}$-globin in heterozygotes.

$\mathrm{Hb} \mathrm{E}$ is an example of an increasing number of structurally abnormal globins that are also synthesized at abnormally low rates. The $\mathrm{Hb}$ Lepore and $\mathrm{Hb}$ Con- stant Spring hemoglobins $(2,3,35)$ are the best known examples. More recently, $\mathrm{Hb}$ Indianapolis, a $\beta$-chain mutant, has been shown to produce $\beta$-thalassemia by profound posttranslational instability of the newly assembled $\beta$-variant, preventing combination with $\alpha$-globin to form hemoglobin tetramers (18). Finally, we have described a profound reduction in the mRNA coding for the $\beta$-chain of $\mathrm{Hb}$ Vicksburg $\left(\beta^{75} \mathrm{Leu} \rightarrow 0\right)$, which exhibits a $\beta$-thalassemia phenotype (39).

Our studies do not explain the mechanism for the thalassemia-like behavior of $\beta^{\mathrm{E}}$-globin genes. It is difficult to envision a precise mechanism whereby the presumed single nucleotide change responsible for the amino acid substitution at position 26 should cause lower globin mRNA production. However, the location of the mutation in codon 26, near the junction of mRNA coding and intervening sequences at codon 30 , could lead to disruption of intranuclear mRNA processing, a mechanism now known to be responsible for some forms of $\beta$-thalassemia (36-38). Alternatively, the mutation could disrupt the secondary structure of $\beta^{\mathrm{E}}$-mRNA, causing instability or decreased template capacity with consequent instability, mechanisms also implicated in $\beta$-thalassemia (35). Finally, $\mathrm{Hb} \mathrm{E}$ could represent a "double mutation," i.e., base substitution occurring on a pre-existing $\beta$-thalassemia allele, a $\beta$ thalassemia occurring on a $\beta^{E}$-globin allele, or a recombination event between two such alleles. These occurrences would not be surprising within a population where both conditions are so frequent. The high frequency of $\mathrm{Hb} \mathrm{E}$ in Southeast Asia could conceivably result from selection for the $\beta$-thalassemia phenotype. The amino acid substitution in $\mathrm{Hb} \mathrm{E}$ may be an incidental feature "carried" through evolution by the same mechanism that preserves $\beta$-thalassemia in many groups. Further exploration of these possibilities can be achieved by studies of mRNA metabolism and restriction endonuclease polymorphisms, using gene blotting techniques (35).

\section{ACKNOWLEDGMENTS}

We are indebted to Dr. Bernard G. Forget for much helpful advice, encouragement, and support throughout these studies, to Alphonse L. Scarpa for excellent technical assistance, and to Ms. Nancy Grinnell for preparation of the manuscript.

This work was supported by grant HL24385 from the National Institutes of Health, and a Basil O'Connor Fellowship to Edward J. Benz, Jr. from the National FoundationMarch of Dimes.

\section{REFERENCES}

1. Fairbanks, V. F., G. S. Gilchrist, B. Brimhall, J. A Joreb, and E. G. Goldstein. 1979. Hemoglobin E trait reexamined: a cause of microcytosis and erythrocytosis. Blood. 53: 109-115.

2. Bunn, H. F., B. G. Forget, and H. M. Ranney. 1972. Human Hemoglobins. W. B. Saunders Co., Philadelphia, Pa. 140-192. 
3. Weatherall, D. J., and J. B. Clegg. 1972. The Thalassemia Syndromes. Blackwell Scientific Publishers, Oxford, England. 75-144, 163-167.

4. Sturgeon, P., H. A. Itano, and W. R. Bergen. 1955. Clinical manifestations of inherited abnormal hemoglobins. II. Interactions of hemoglobin $\mathrm{E}$ and thalassemia trait. Blood. 10: $396-404$.

5. Chernoff, A. I., V. Minnich, S. Na-Nakorn, S. Tuchinda, C. Kashemsant, and R. P. Chernoff. 1956. Studies of hemoglobin E. I. The clinical, laboratory, and genetic characteristics of hemoglobin E syndrome. J. Lab. Clin. Med. 47: 455-498.

6. Pagnier, J., H. Wajeman, and A. Labie. 1974. Defect in hemoglobin synthesis possibly due to a disturbed association. FEBS (Fed. Eur. Biochem. Soc.) Lett. 35: 252-255.

7. Weatherall, D. J., J. B. Clegg, S. Na-Nakorn, and P. Wasi. 1969. The pattern of disordered haemoglobin synthesis in homozygous and heterozygous $\beta$-thalassaemia. $\mathrm{Br}$. J. Haematol. 16: 251-257.

8. Feldman, R., and R. Rieder. 1973. The interaction of hemoglobin $\mathrm{E}$ with $\beta$-thalassemia: a study of hemoglobin synthesis in a family of mixed Burmese and Iranian origin. Blood. 42: 783-791.

9. Testa, U., A. Dubart, N. Hinard, F. Galacteros, W. Vainchencker, P. Rouyer-Fessard, Y. Beuzard, and J. Rosa. 1980. $\beta^{\circ}$-Thalassemia/Hb E association. Acta Haematol. 64: 42-52.

10. Fairbanks, V. F., R. Oliveros, J. H. Brandabor, R. R. Willis, and R. F. Fiester. 1980. Homozygous Hb E mimics $\boldsymbol{\beta}$-thalassemia minor without hemolysis or anemia. Am. J. Hematol. 8: 109-121.

11. Finer, M., J. R. Humbert, and S. L. Friedman, 1979. Globin synthesis in hemoglobin E- $\beta^{\circ}$-thalassemia. Blood. 54: 53A.

12. Ruymann, F. B., L. A. Popejoy, and R. B. Bronillard. 1978. Splenic sequestration and ineffective erythropoiesis in hemoglobin E- $\beta$-thalassemia disease. Ped. Res. 12: $1020-1023$.

13. Benz, E. J. Jr., P. S. Swerdlow, and B. G. Forget. 1975. Absence of functional messenger RNA activity for $\beta$ globin chain synthesis in $\beta^{0}$-thalassemia. Blood. 45: $1-10$.

14. Housman, D., B. G. Forget, A. Skoultchi, and E. J. Benz, Jr. 1973. Quantitative deficiency of chain-specific globin messenger ribonucleic acids in the thalassemia syndrome. Proc. Natl. Acad. Sci. U. S. A. 70: 1809-1813.

15. Forget, B. G., D. Housman, E. J. Benz, Jr., and R. P. McCaffrey. 1975. Synthesis of DNA complementary to separated human $\alpha$ and $\beta$ globin messenger RNAs. Proc. Natl. Acad. Sci. U. S. A. 72: 984-988.

16. Benz, E. J., Jr., B. G. Forget, D. G. Hillman, M. CohenSolal, J. Pritchard, C. Cavallesco, W. Prensky, and D. Housman. 1978. Variability in the amount of $\beta$ globin messenger RNA in $\beta^{\circ}$-thalassemia. Cell. 14: 299-312.

17. Benz, E. J., Jr., and B. G. Forget. 1971. Defect in messenger RNA for human hemoglobin synthesis in $\beta$-thalassemia. J. Clin. Invest. 50: 2755-2760.

18. Adams, J. G., III, L. A. Boxer, R. L. Baehner, B. G. Forget, G. A. Tsistrakis, and M. H. Steinberg. 1979. Hemoglobin Indianapolis ( $\beta 112$ [G14]arginine): an unstable $\beta$ chain variant producing the phenotype of severe $\beta$-thalassemia. J. Clin. Invest. 63: 931-938.

19. Benz, E. J., Jr., P. S. Swerdlow, and B. G. Forget. 1973. Globin messenger RNA in hemoglobin $\mathrm{H}$ disease. Blood. 42: 825-833.

20. Nathan, D. G., H. F. Lodish, Y. W. Kan, and D. Housman. 1971. $\beta$-Thalassemia and translation of globin messenger RNA. Proc. Natl. Acad. Sci. U. S. A. 68: 2514-2518.
21. Adams, J. G., W. P. Winter, K. Tausk, and P. Heller. 1974. Hemoglobin Rush ( $\beta^{101}[\mathrm{G} 3]$ glutamine): a new unstable hemoglobin causing mild hemolytic anemia. Blood. 43: 261-269.

22. Benz, E. J., Jr., C. E. Geist, A. W. Steggles, J. E. Barker, and A. W. Nienhuis. 1977. Hemoglobin switching in sheep and goats. VII. Purification and characterization of $\mathrm{cDNAs}$ complementary to sheep $\alpha, \beta$, and $\gamma$ mRNAs of sheep. J. Biol. Chem. 252: 1908-1916.

23. Traeger, J., W. G. Wood, J. B. Glegg, D. J. Weatherall, and P. Wasi. 1980. Defective synthesis of $\mathrm{Hb} \mathrm{E}$ is due to reduced levels of $\beta^{\mathrm{E}}$ mRNA. Nature (Lond.). 288: 497-499.

24. Rieder, R. F. 1975. Variations in the synthesis and cellular content of structurally distinct human hemoglobins. In Sickle Cell Anemia and Other Hemoglobinopathies. Academic Press, Inc., New York. 25-49.

25. Kim, H. C., R. G. Weierbach, S. Friedman, and E. Schwartz. 1977. Detection of sickle $\alpha$ or $\beta^{\circ}$-thalassemia by studies of globin biosynthesis. Blood. 49: 785-792.

26. Kim, H. C., R. G. Weierbach, S. Friedman, and E. Schwartz. 1977. Globin biosynthesis in sickle cell, Hb SC, and $\mathrm{Hb} \mathrm{C}$ diseases. J. Pediatr. 91: 13-18.

27. Steinberg, M. H., and B. J. Dreiling. 1976. Clinical hematologic and biosynthetic studies in sickle cell- $\beta^{0}$. thalassemia: a comparison with sickle cell anemia. Am. J. Hematol. 1: 35-44.

28. White, J. M. 1971. The synthesis of abnormal hemoglobins. Semin. Haematol. 4: 116-130.

29. Benz, E. J., Jr., and B. G. Forget. 1974. The biosynthesis of hemoglobin. Semin. Hematol. 11: 463-523.

30. Nienhuis, A. W., P. H. Canfield, and W. F. Anderson. 1973. Hemoglobin messenger RNA from human bone marrow: isolation and translation in homozygous and heterozygous $\beta$-thalassemia. J. Clin. Invest. 52: 1735-1745.

31. Natta, C., J. Banks, G. Niazi, P. A. Marks, and A. Bank. 1973. Decreased $\beta$ globin mRNA activity in homozygous and heterozygous $\beta$-thalassemia. Nature (New Biol.). 244: 280-281.

32. Frischer, H., and J. Bowman. 1975. Hemoglobin E, an oxidatively unstable mutation. J. Lab. Clin. Med. 85; 531-539.

33. Ali, M. A. M., A. Quinlan, and S. C. Wong. 1980. Identification of hemoglobin $\mathrm{E}$ by the isopropanol solubility test. Clin. Biochem. 13: 146-148.

34. Higgs, D. R., J. M. Old, L. Pressley, J. B. Clegg, and D. J. Weatherall. 1980. A novel $\alpha$ globin gene arrangement in man. Nature (Lond.). 284: 632-635.

35. Benz, E. J., Jr., and B. G. Forget. 1980. The pathogenesis of the thalassemia syndromes. Pathobiol. Rep. 10: 1-33.

36. Maquat, L. E., A. J. Kinniburgh, L. R. Beach, G. R. Honig, J. Lazerson, W. B. Ershlev, and J. Ross. 1980. Processing of $\beta$ globin mRNA precursor to mRNA is defective in three patients with $\beta^{+}$-thalassemia. Proc. Natl. Acad. Sci. U. S. A. 77: 4287-4291.

37. Kantor, J. A., P. H. Turner, and A. W. Nienhuis 1980 $\beta$-Thalassemia: mutations which affect processing of the $\beta$ globin mRNA precursor. Cell. 21: 149-157.

38. Benz, E. J., Jr., A. L. Scarpa, J. K. deRiel, B. L. Tonkonow, A. K. Ritchey, and B. G. Forget. 1981. Globin messenger RNA metabolism in normal and thalassemic erythroblasts. In Hemoglobins in Differentiation and Development. A. W. Nienhuis and G. Stamatoyannopoulos, editors. Alan R. Liss, Inc., New York. In press.

39. Adams, J. G. III, M. H. Steinberg, M. V. Newman, T: W. Morrison, E. J. Benz, Jr., and R. Iyer. 1981. $\beta$ Thalassemia present in cis to a new $\beta$ chain structural variant: Hb Vicksburg $\left(\beta^{73}[\mathrm{E} 19]\right.$ Leu $\left.\rightarrow 0\right)$. Proc. Natl. Acad. Sci. U. S. A. 78: 469-473. 